\title{
Enabling the diffusion of sustainable product innovations in BIM library platforms
}

\author{
Soheila Bahrami \\ soheila.bahrami@construction.lth.se | Division of Construction Management, Faculty of Engineering, \\ Lund University, Box 118, 22100, Lund, Sweden

\section{Brian Atkin} \\ brian.atkin@construction.lth.se|Division of Construction Management, Faculty of Engineering, Lund \\ University, Box 118, 22100, Lund, Sweden \\ Anne Landin \\ anne.landin@construction.lth.se | Division of Construction Management, Faculty of Engineering, Lund \\ University, Box 118, 22100, Lund, Sweden
}

\begin{abstract}
Building Information Modelling (BIM) objects represent building products in design, simulation, and procurement processes. This paper explores how BIM objects could be created and exchanged to enable the diffusion of innovative products with enhanced sustainability performance. Two BIM library platforms were examined by taking a new approach that integrates the concepts of sustainable value, diffusion of innovations, information, software usability, and platform ecosystems. The findings show that the diffusion of sustainable products can be inhibited due to problems with the mechanisms for creating and exchanging BIM objects, quality of BIM objects, the usability of BIM library platforms, and participation on the platforms. This study deepens an understanding of the problems by focusing on ventilation products in Sweden. Identified shortcomings in the current practices of BIM platform owners and participants could be reduced by effective platform strategies, certification schemes for BIM objects, and BIM object creation processes integrated with product lifecycle management.
\end{abstract}

Keywords. Innovation diffusion; BIM object; BIM library platform; sustainable value; product information management; software usability.

Cite paper as: Bahrami, S., Atkin, B., Landin, A., (2019). Enabling the diffusion of sustainable product innovations in BIM library platforms, Journal of Innovation Management, www.open-jim.org, 7(4), 106-130. 


\section{Introduction}

Building Information Modelling (BIM) is widely considered as the main tool for the exchange of digital information about buildings throughout their lifecycles. On BIM library platforms, BIM objects represent products such as ventilation system components within applications including design, simulation, and purchasing processes. Thus, BIM libraries have a central role in disseminating information about innovative products.

In Sweden, some heating, ventilation, and air conditioning (HVAC) manufacturers have attempted to create value through sustainable innovations such as patented solutions for controlling airflow and noise in their ventilation products (World Intellectual Property Organization, 2015, 2018). Diffusion of such innovations can enhance the indoor environmental quality and the sustainability performance of buildings. However, the retrieval of accurate information (Gao et al., 2017) and valid comparisons between building products is limited due to the heterogeneous methods by which building product information is provided (Bahrami et al., 2019) and BIM objects are created (Gao et al., 2017).

In the context of innovation diffusion, researchers have studied BIM as a process innovation (Bosch-Sijtsema et al., 2017; Gholizadeh et al., 2018; Gledson, 2017) in relation to standardization (Hooper, 2015) and its evolution as a digital infrastructure (Holmström et al., 2014). However, previous studies have overlooked the role of BIM in creating sustainable value through the diffusion of product innovations. In the context of information, studies on BIM objects have focused on one aspect, such as software structure (e.g. McGlinn et al., 2017), product information management (e.g. Palos et al., 2014), or information retrieval (e.g. Gao et al., 2017). There is still a need for a holistic approach in studying the creation and exchange of BIM objects in relation to the diffusion of sustainable innovations. This need is critical for BIM objects of HVAC products due to their major impact on the sustainability performance of buildings. Hence, efficient BIM object library platforms are required to direct HVAC design and simulation processes towards selecting products with enhanced sustainability performance. The growing number of BIM applications (Gao et al., 2017; Pasini et al., 2017) offers a pivotal role to BIM library platforms as ecosystems in which BIM objects are created and exchanged. However, research to date has not investigated platform business strategies adopted in BIM libraries.

The study presented here aims to explore the creation and exchange of BIM objects on BIM library platforms for supporting the diffusion of sustainable HVAC innovations. The focus is on the ventilation BIM objects on two BIM library platforms used in Sweden. The BIM objects are manufacturers' objects based on products available on the market. In this paper, sustainable innovations are ventilation products with enhanced sustainability attributes. The sustainability attributes are energy efficiency, indoor environmental quality performance, and carbon footprint of the products. A new approach has been developed by modifying and integrating elements and methods from related research fields. The conceptual framework is broad in order to address the areas neglected in previous studies. On the other hand, this work deepens the understanding about BIM objects by focusing on ventilation products with enhanced sustainability attributes. The implications of these findings concern the stakeholders involved in creating and exchanging BIM objects. 
The remainder of the paper has the following structure. First, it gives a review of related previous research conducted on the concepts of sustainable value, diffusion of innovations, quality of information, usability of BIM libraries, and platform ecosystems. Next, it describes the research method, which has been developed by integrating these concepts and designing a multiple case study, consisting of two BIM library platforms. The subsequent section discusses the findings in relation to the conceptual framework and the implications for BIM platform owners, HVAC manufacturers, and researchers. The final section summarizes the main findings of this study and identifies areas for further research.

\section{Literature review}

The literature on sustainable value, diffusion of innovations, information quality, usability and platform ecosystems are reviewed to construct a conceptual framework for this study. Sustainable value is defined as mutual benefits for society, the environment, and a firm, which can be cocreated through collaborative relationships between stakeholders (Sulkowski et al., 2018). Firms can benefit from developing new business models and sustainable offerings through sustainable value chains (Nidumolu et al., 2009). To capture sustainable value from their innovations, firms must effectively communicate the advantages of their offerings. For ventilation products, the common sustainability indicators are energy efficiency and indoor environmental performance, including indoor air quality, thermal comfort, and acoustic performance (Sweden Green Building Council, 2019). Manufacturers can also quantify and communicate the sustainability impacts of their products by reporting the carbon footprint of their products. This indicator is defined as the net sum of greenhouse gas emissions and removals in a product system, expressed as carbon dioxide equivalents based on a life cycle assessment (ISO, 2018).

The process in which an innovation is communicated over time among members of a social system is referred to as the diffusion of innovations (Rogers, 2003). Research has shown that as suggested by epidemic (Bass, 2004) and bandwagon theories (Rogers, 2003), the diffusion of innovations is driven by information dissemination (Frattini et al., 2014). It begins with communicating the information about the existence of an innovation, while its success depends on the user's perception of the following characteristics of the innovation (Rogers, 2003).

- Relative advantage: the degree to which an innovation is perceived as better than other offerings

- Compatibility: the degree to which an innovation is perceived as being consistent with user values

- Complexity: the degree to which an innovation is perceived as difficult to understand and use

- Trialability: the degree to which an innovation can be assessed

- Observability: the degree to which the performance of an innovation is visible

Information serves to influence the receiver's perception of something (Davenport \& Prusak, 2000). Firms can provide information on the relative advantages of their offerings by persuasive 
value propositions (Anderson et al., 2009). They can utilize value propositions as strategic tools to communicate (Payne et al. Eggert, 2017) the benefits customers can gain from their offerings (Osterwalder et al., 2014) when compared with the alternatives offered by their competitors (Lindic \& Silva, 2011). To communicate the relative advantage of their sustainable innovations, firms must employ sustainable value propositions. A sustainable value proposition is defined as "a promise on the economic, environmental, and social benefits that a firm's offering delivers to customers and society at large, considering both short-term profits and long-term sustainability" (Patala et al., 2016). The compatibility of an innovation accelerates its diffusion (Olson, 2013; Rogers, 2003); whereas, complexity decelerates the diffusion (Grimpe et al., 2017; Rogers, 2003). Trialability and observability are characteristics influencing the level of uncertainty about an innovation faced by potential adopters (Hall, 2006). Various sources and types of information about an innovation enable its diffusion by reducing uncertainty about its attributes, use, and impacts (Rice, 2017).

The growing application of BIM has made BIM libraries significant sources of product information, which is presented in the form of BIM objects (Gao et al., 2017; Pasini et al., 2017). A BIM object is a data file detailing information about the identity, dimensions, appearance, and performance of a product (BSI, 2018). It can facilitate the trialability and observability of an innovative product in a virtual environment, and consequently foster its diffusion. Nonetheless, this cannot be achieved if BIM objects lack sufficient quality; of particular concern are the technical data and features required for HVAC design calculations and performance simulations, due to their impact on the perceived sustainability performance of products. Therefore, in order to enable the diffusion of sustainable HVAC innovations, BIM objects representing such products must contain high-quality information.

Information quality is defined as "desirable characteristics of the (information) system outputs" (Peter et al., 2013). It can be assessed by indicators such as relevance (Holliman \& Rowley, 2014; Myrelid \& Jonsson, 2019; Pazeraite \& Repoviene, 2016; Peter et al., 2013), accuracy, currency, usefulness (Holliman \& Rowley, 2014; Peter et al., 2013), sufficiency, comprehensibility (Myrelid \& Jonsson, 2019; Peter et al., 2013), accessibility (Myrelid \& Jonsson, 2019), and reliability (Myrelid \& Jonsson, 2019; Pazeraite \& Repoviene, 2016). An attempt to assess the quality of BIM objects is the BSI Kitemark for BIM objects, a third-party certification scheme to validate the accuracy and functionality of BIM objects (BSI, 2018). A shortcoming of the existing BIM libraries is that they provide different names (Chen et al., 2017) and types of information for products in the same category made by different manufacturers (Gao et al., 2017; Pasini et al., 2017). Dissimilarities between two distinct methods of representing data stem from different types of data, value differences, semantic differences, and missing values (Anumba et al., 2008). A recent study has identified the problem of dissimilarities in product information provided by HVAC manufacturers in Sweden as a potential barrier to the diffusion of innovations (Bahrami et al., 2019). Product lifecycle management (PLM) is a system for the integrated management of product information and processes through the product lifecycle (Schuh et al., 2008), which can be applied to facilitate the diffusion of innovations (Stark, 2015). PLM tools enable integrating business information with engineering information (Ferreira et al., 2017). So far, however, integrating the creation of BIM objects with the PLM tools has not been investigated. 
Unlike the cost of information which is determined by the producer, the value of information is determined by the user (Feather, 2013). The value of information is not inherent in information itself, but rather dependent on its availability, suitability (Feather, 2013), context, and use (Rowley, 2008). Therefore, providing valuable information for users depends not only on the quality of information, but also on how the information can be used. On BIM library platforms, users access the product information through the BIM library interfaces. This shows how the usability of BIM library interfaces is a significant factor in the value of their information. The ISO/IEC 25062 standard defines usability as "the extent to which a product can be used by specified users to achieve specified goals with effectiveness, efficiency, and satisfaction in a specified context of use" (ISO, 2019). For example, the usability of a software tool for improving energy efficiency in buildings has been evaluated by investigating whether the data can be accessed and comprehended by facility managers (McGlinn et al., 2017). Software usability can also be evaluated by investigations on searching, differentiating, and selecting behavior at the resource, source, document, and content levels (Makri et al., 2008). However, previous studies have overlooked this approach in investigating the usability of BIM library interfaces. Factors affecting the usability of an interface include informativeness, reachability of desired content, density, readability, and comprehensibility of the information (Speicher et al., 2015), and credibility of the website (Holliman \& Rowley, 2014). Some usability problems are primarily system issues arising when information or functionality is missing, inadequate, misplaced, unnecessary, or misaligned (Tarkkanen et al., 2015). In this paper, the term usability is defined as the functionality and applicability of a BIM library interface in promoting innovative products with enhanced sustainability performance.

The most common BIM libraries are provided on digital platforms; for example, SmartBIM library (SmartBIM, 2018), Bimobject platform (Bimobject, 2019), NBS National BIM library (National Building Specification, 2019), and MagiCloud (MagiCAD, 2019). The platform business model enables external producers and consumers to create value in an interactive ecosystem (Parker et al., 2017b), and is used as an effective strategy for delivering innovations (Kim, 2016). Information technology platforms, in particular, can reform innovation ecosystems (Parker et al., 2017). In a platform ecosystem, value is co-created through iterative and reciprocal processes of shaping institutional arrangements (Fehrer et al., 2018) by all participants in a complex value matrix instead of the traditional linear value chain (Parker et al. 2017b). In innovation ecosystems, innovative firms must collaborate with other actors to achieve a complex value proposition (Talmar et al., 2018). Every platform has a core interaction defined by three key elements: the participants, the value unit, and the algorithmic software tool (filter) for delivering the value unit to the users (Parker et al., 2017a). Information and interactions are the principal assets in platform businesses (Van Alstyne et al., 2016), and because every interaction starts with the exchange of information, even platforms intended to exchange physical goods must facilitate the exchange of information (Parker et al., 2017a). In addition, platform owners need to define and adjust the optimum level of openness of their platforms continuously (Van Alstyne \& Parker, 2017). Openness enables access to user creativity (Kohler \& Chesbrough, 2019) and third-party developers' innovations (Parker \& Van Alstyne, 2018); however, open platforms are more fragmented and more difficult to monetize and control (Parker et al., 2017), which can result in poor quality contributions (Van Alstyne \& Parker, 2017). Platforms can develop a culture of quality control to create value units which are relevant, useful, and accurate (Parker et al., 2017a). 
Although platform is the common business strategy for BIM libraries, the effects of different platform structures on the creation and exchange of BIM objects has yet to be understood. Previous research has investigated the role of information, promotion (Song \& Parry, 2009), social media (Bhimani et al., 2019), and early adopters in the diffusion of innovative products (Bianchi et al., 2017). However, the role of BIM library platforms in disseminating information about innovative building products for sustainability, and supporting the diffusion of such innovation, has not been studied thus far. In the fields of information and software usability, there is still a need for a holistic approach to study product information and software structure, while considering the needs of specific BIM users (e.g. the HVAC sector); particularly, with a focus on the sustainability attributes of BIM objects as user requirements. Limited understanding about these issues runs the risk of restricting the diffusion of sustainable innovations.

\section{Methodology}

The literature review has revealed that a holistic approach needs to be developed for investigating the creation and exchange of BIM objects on BIM library platforms in support of the diffusion of sustainable innovations. To address this need, the conceptual framework of this study (Figure 1) has been established by integrating the concepts of sustainable value, diffusion of innovations, information quality, software usability, and platform ecosystems.

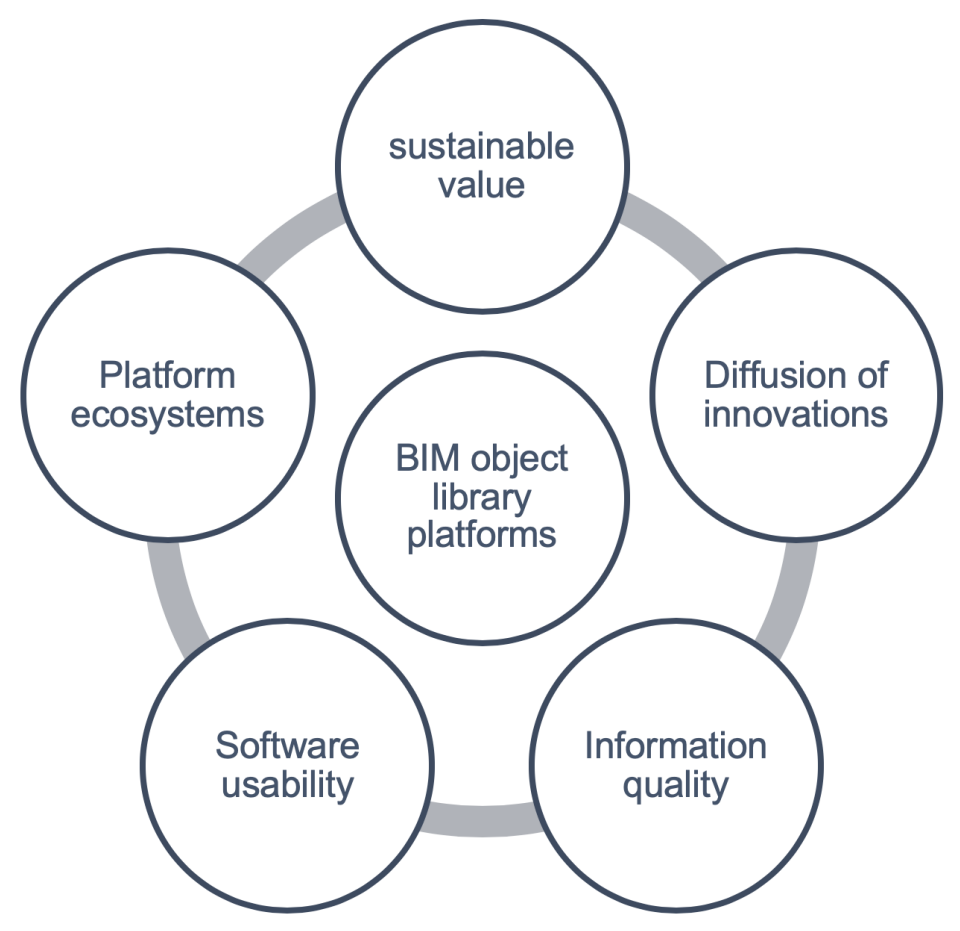

Fig. 1. The conceptual framework for studying the role of BIM object library platforms in the diffusion of sustainable innovations

The methodology of this study is qualitative, characterized by selecting and juxtaposing an 
assortment of relevant information to develop an in-depth understanding of interconnected phenomena (Young \& Munksgaard, 2018). A qualitative approach is an effective way of conducting research in the field of management (Singh, 2015). It allows researchers to use various sources of information (Yin, 2016) to establish the basis for retroductive reasoning through inferring patterns and causation from different data sources (Kessler \& Bach, 2014). Moreover, in qualitative research, the emphasis is on words rather than quantifications (Bryman \& Bell, 2015) as this enables the study of textual information in BIM objects especially when the information is limited.

As one of the approaches in qualitative research (Creswell \& Poth, 2018), this study has adopted a multiple-case study approach. It is an effective empirical approach for investigating a contemporary phenomenon in depth and within its real-world context (Yin, 2018), and has been applied in studies on BIM in the contexts of the diffusion of innovations (Gledson, 2017), usability (McGlinn et al., 2017), and standardization (Hooper, 2015). Figure 2 illustrates the multiple-case design for this study, which covers two cases in the context of the diffusion of sustainable product innovations. The cases are two BIM library platforms referred to as platform A and platform B in this paper, details of which are provided in the next section. Based on the key elements of the core interaction on a platform suggested by Parker et al. (2017a), the embedded units of analysis in each case are participants, BIM library platform, and BIM objects. The platforms have been selected based on the results of an initial survey on the BIM libraries commonly used by HVAC design engineers in Sweden. The respondents were from seven major and three medium-sized architecture, engineering, and construction (AEC) companies in the country. The cases have been selected-to-difference (Kessler \& Bach, 2014) that enables investigating how different aspects of the platforms affect the creation and exchange of BIM objects and the diffusion of sustainable innovations. An initial review of the platforms' websites revealed a considerable difference between the platforms regarding the number of BIM objects and their offerings.

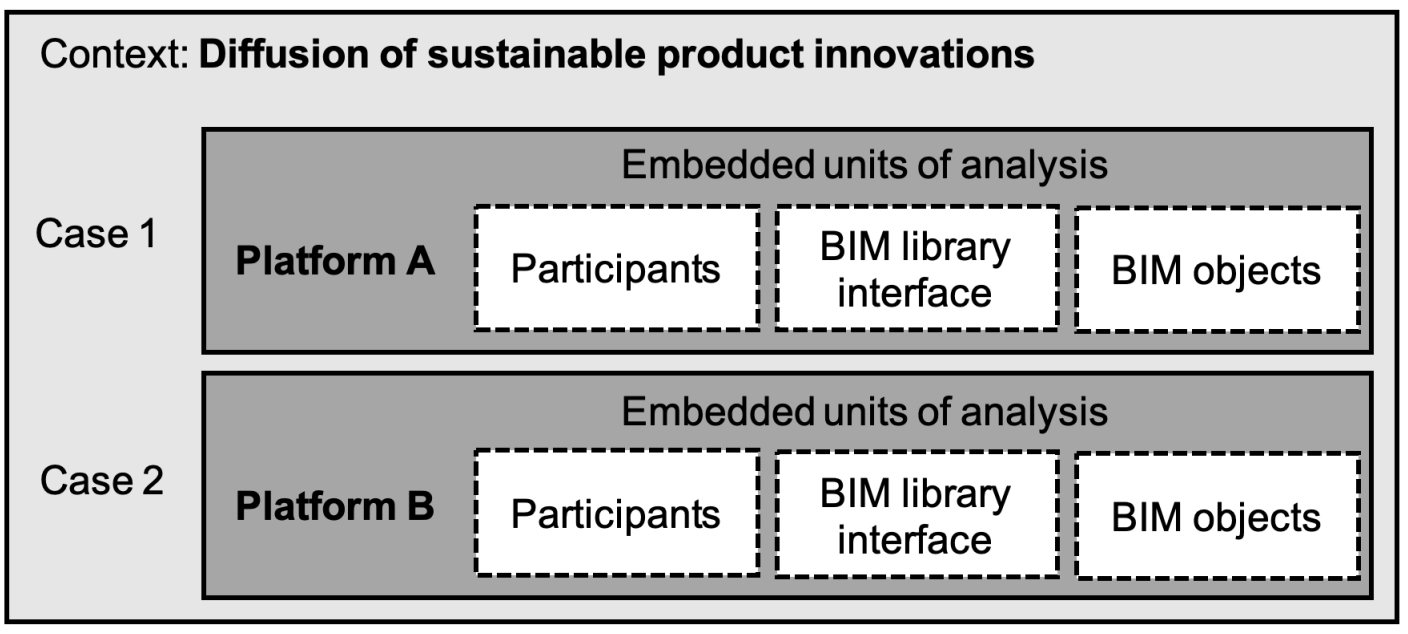

Fig. 2. Multiple-case study design

Next, based on abductive re-description and re-contextualization of the conceptual framework components (Bhaskar, 2014; Danermark et al., 2002), a tool for data collection and analysis was developed in three stages. First, the matrix shown in figure 3 was developed by integrating 
the concepts of platform ecosystems, software usability, and information quality in order to reconceptualize the BIM library platforms. The creation and exchange of BIM objects has been determined as the core interaction on BIM library platforms. The key elements of this core interaction are BIM object producers and users, BIM library interface, and BIM objects. The criteria determined for assessing the key elements are participation quality, usability, and information quality. The indicators have been selected and modified from the literature reviewed in previous section.

\begin{tabular}{|c|c|c|}
\hline Key elements & Criteria & Indicators \\
\hline $\begin{array}{l}\text { Participants (BIM object } \\
\text { producers and users) }\end{array}$ & Participation quality & $\begin{array}{l}\text { Access to BIM objects } \\
\text { Participant categories } \\
\text { Roles } \\
\text { Attraction } \\
\text { Control }\end{array}$ \\
\hline Filter (BIM library interface) & Usability & $\begin{array}{l}\text { Availability of desired content } \\
\text { Searchability of desired content } \\
\text { Comparability of BIM objects }\end{array}$ \\
\hline Value unit (BIM object) & Object quality & $\begin{array}{l}\text { Compatibility } \\
\text { Functionality }\end{array}$ \\
\hline & Information quality & $\begin{array}{l}\text { Accessibility } \\
\text { Accuracy } \\
\text { Adequacy } \\
\text { Comprehensibility } \\
\text { Currency } \\
\text { Applicability } \\
\text { Reliability }\end{array}$ \\
\hline
\end{tabular}

Fig. 3. Matrix for the qualitative analysis of BIM library platforms

Table 1. The characteristics of a sustainable innovative product represented by its BIM object to enable its diffusion (After Rogers, 2003)

\begin{tabular}{ll}
\hline Relative advantage & $\begin{array}{l}\text { The superiority of the sustainability attributes of an innovative } \\
\text { product over other brands }\end{array}$ \\
\hline Compatibility & $\begin{array}{l}\text { The degree to which the sustainability attributes of an } \\
\text { innovative product comply with the users' requirements }\end{array}$ \\
\hline Complexity & $\begin{array}{l}\text { The difficulty of understanding the information about the } \\
\text { sustainability performance of an innovative product }\end{array}$ \\
\hline Trialability & $\begin{array}{l}\text { The possibility of using a BIM object to perform more } \\
\text { accurate design and sustainability performance calculations }\end{array}$ \\
\hline Observability & $\begin{array}{l}\text { The accuracy of the simulated sustainability performance of an } \\
\text { innovative product compared to its actual performance }\end{array}$ \\
\hline
\end{tabular}


Second, the characteristics of an innovation suggested by Rogers (2003) were redefined by integrating the concepts of sustainable value and the diffusion of innovations and re-contextualizing BIM library platforms in the setting of the diffusion of sustainable innovations (table 1). Third, the questions listed in table 2 were formulated to integrate the indicators shown in figure 3 with the definitions in table 1 . The questions enabled the retroduction of possible explanatory mechanisms or structures as a necessity in interdisciplinary research (Bhaskar et al., 2010) and the implementation of a holistic approach in data collection and analysis.

In qualitative research, data collection and analysis, and report writing are interrelated and often concurrent (Creswell \& Poth, 2018)). In this study, those processes took place concurrently from September 2018 to September 2019. Case study research relies on multiple sources of evidence (Yin, 2018) including observations, audio-visual material, documents, reports, and interviews (Creswell \& Poth, 2018). The data regarding the structure of the platforms was collected from the platforms' websites, YouTube channels and LinkedIn pages. This study has focused on HVAC professionals in AEC companies as the users of BIM libraries. Thus, the data regarding the usability of the BIM library interfaces and the quality of BIM objects was collected and analyzed by one of the co-authors proficient in HVAC design software and an HVAC design expert. As suggested by Creswell and Poth (2018) data was collected in natural settings sensitive to the objects under study. The data was collected through critically studying approximately seven hours of webinars, tutorial, and demonstration videos on the platforms' websites and their YouTube channels as well as studying six hours of tutorial videos made by HVAC designers and shared on YouTube. The latter has served as a valuable source of data in natural settings that allows the researcher to observe different ways of using the BIM libraries and objects by HVAC professionals.

In addition, the participant observation method (Bryman \& Bell, 2015) was followed through which the abovementioned members of the research team used the BIM platform libraries and their BIM objects in common HVAC design software. The aim was to answer the questions listed in table 2 regarding the usability of the interface as well as the compatibility and functionality of the BIM objects. In total, 80 ventilation BIM objects composed of 50 objects from platform A and 30 objects from platform $\mathrm{B}$ were selected for analysis. The reason for selecting fewer objects from platform B was the number of available objects on the platform. Content and semantic analysis (Young \& Munksgaard, 2018) was applied to explore the quality of BIM objects. The keywords were selected based on the sustainability attributes (i.e. energy efficiency, indoor environmental quality performance, and carbon footprint of products). The keywords were completed by adding units and different terms adopted in the industry. For example, "db", "sound", "noise", and "acoustic" for searching information about the acoustic performance as one of the aspects of indoor environmental quality.

For each platform, a within-case analysis was performed through the analysis of each embedded unit (figure 2) followed by a process-tracing method (Beach \& Pedersen, 2013; Goertz \& Mahoney, 2012 ) to conduct an analysis across the three embedded units. Furthermore, a cross-case analysis of the platforms was conducted in order to externally validate the findings from the analysis of each platform by cross-case comparison (Frattini et al., 2014). It was conducted by exploring patterns, themes, differences, and similarities across the cases (Creswell \& Poth, 2018; Mathison, 
Table 2. Questions for data collection and analysis

\begin{tabular}{|c|c|c|}
\hline & Indicators & Questions \\
\hline \multirow{5}{*}{ 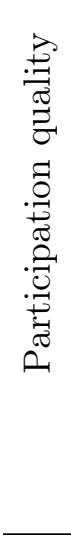 } & $\begin{array}{l}\text { Access to BIM } \\
\text { objects }\end{array}$ & $\begin{array}{l}\text { How open is the access to the BIM objects published on the } \\
\text { platform? }\end{array}$ \\
\hline & $\begin{array}{l}\text { Participant } \\
\text { categories and } \\
\text { roles }\end{array}$ & Who are the BIM object creators and users? \\
\hline & Attraction & How does the platform attract the participants to the platform? \\
\hline & Facilitation & $\begin{array}{l}\text { How does the platform facilitate the creation and exchange of } \\
\text { BIM objects on the platform? }\end{array}$ \\
\hline & Control & $\begin{array}{l}\text { How does the platform control and assure the quality and } \\
\text { reliability of the BIM objects? }\end{array}$ \\
\hline \multirow{3}{*}{ 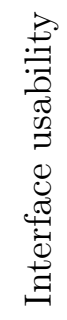 } & $\begin{array}{l}\text { Availability of } \\
\text { desired content }\end{array}$ & $\begin{array}{l}\text { Does the library have BIM objects for all ventilation products } \\
\text { available on the market? }\end{array}$ \\
\hline & $\begin{array}{l}\text { Searchability of } \\
\text { desired content }\end{array}$ & $\begin{array}{l}\text { Do the search criteria include the sustainability attributes of } \\
\text { products? }\end{array}$ \\
\hline & $\begin{array}{l}\text { Comparability of } \\
\text { products }\end{array}$ & $\begin{array}{l}\text { Does the interface enable its users to compare the sustainability } \\
\text { attributes of different brands? }\end{array}$ \\
\hline \multirow{9}{*}{ 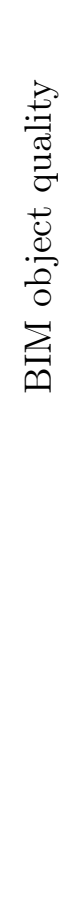 } & Compatibility & $\begin{array}{l}\text { Is the object compatible with common design and calculation } \\
\text { software? }\end{array}$ \\
\hline & Functionality & $\begin{array}{l}\text { Is the object sufficient for performing accurate calculations and } \\
\text { simulations? }\end{array}$ \\
\hline & Accessibility & $\begin{array}{l}\text { Can users easily access the information about the sustainability } \\
\text { attributes of the product in the content of a selected object? }\end{array}$ \\
\hline & Accuracy & $\begin{array}{l}\text { Is the information on the sustainability attributes of the products } \\
\text { accurate? }\end{array}$ \\
\hline & Adequacy & $\begin{array}{l}\text { Is sufficient information on the sustainability attributes of the } \\
\text { products included in the BIM objects? }\end{array}$ \\
\hline & Comprehensibility & $\begin{array}{l}\text { Does the information give a clear understanding of the } \\
\text { sustainability attributes of the product? }\end{array}$ \\
\hline & Currency & Is the information up to date? \\
\hline & $\begin{array}{l}\text { Applicability of } \\
\text { the content }\end{array}$ & $\begin{array}{l}\text { Does the information enable the user to compare different brands } \\
\text { and choose the products with better sustainability attributes? }\end{array}$ \\
\hline & Reliability & $\begin{array}{l}\text { Has the information on the sustainability attributes been verified } \\
\text { or certified? }\end{array}$ \\
\hline
\end{tabular}


2005). As proposed by Creswell and Poth (2018), both inductive and deductive reasoning were used to analyze the data.

The researcher's professional experience is considered to be an important analytical tool in qualitative data analysis (Mauthner \& Doucet, 2003), which utilizes personal reflection to seek insights in research on business relationships, networks, and markets (Young \& Munksgaard, 2018). In this study, the authors' long experience of AEC management as well as HVAC and IT engineering and management was applied to analyze the data and identify the problems. In addition, diverse sources of data helped the authors to cross-check and verify (Saunders, Lewis, \& Thornhill, 2009) the identified problems and minimize the risk of researcher bias. Furthermore, to ensure the interpretative validity (Huberman \& Miles, 2002) of findings, eight semi-structured interviews were conducted. The interviews were conversational in order to answer questions listed in table 2, complete and verify the findings, and include the aspects that could possibly be neglected by the authors. Regarding the usability of platforms and the quality of the BIM objects, six semi-structured interviews were conducted with IT, product, and marketing managers in three major HVAC manufacturing companies, and three HVAC design engineers in three major AEC companies. As mentioned, regarding the information quality and usability, this study focuses on the characteristics of the BIM objects and the BIM library interfaces. Therefore, experienced HVAC designers were selected as interviewees in order to exclude the probable problems caused by insufficient knowledge of users. The industry validation (Leising, Quist, \& Bocken, 2018) was continued by two semi-structured in-depth interviews with the area and technical managers in the platform companies. The interviews were conversational and based on the questions listed in table 2. They were recorded, transcribed, and coded based on the indicators mentioned in figure 3 and the characteristics defined in table 1 . After analyzing the final results, the findings were visualized and are described in relation to the conceptual framework in the following section.

\section{Findings and discussion}

This study set out to assess the creation and exchange of ventilation BIM objects as the core interaction on two BIM library platforms in Sweden. The findings indicate that both platforms have problems with participation, the usability of the BIM libraries, and the quality of BIM objects.

\subsection{Participation on the platforms}

Spreading the information on products with enhanced sustainability performance is the first step in the diffusion of such innovations. However, this study found that limited participation on the platforms has reduced the access to information about the existence of innovative products. Platform A targets the mechanical, electrical, and plumbing (MEP) sector (including HVAC) as a niche market. Figure 4 demonstrates the interactions among the participants on the platform. The platform company offers a BIM library platform and BIM software for MEP design and energy modelling of buildings that complement AutoCAD and Revit. It also creates BIM objects 


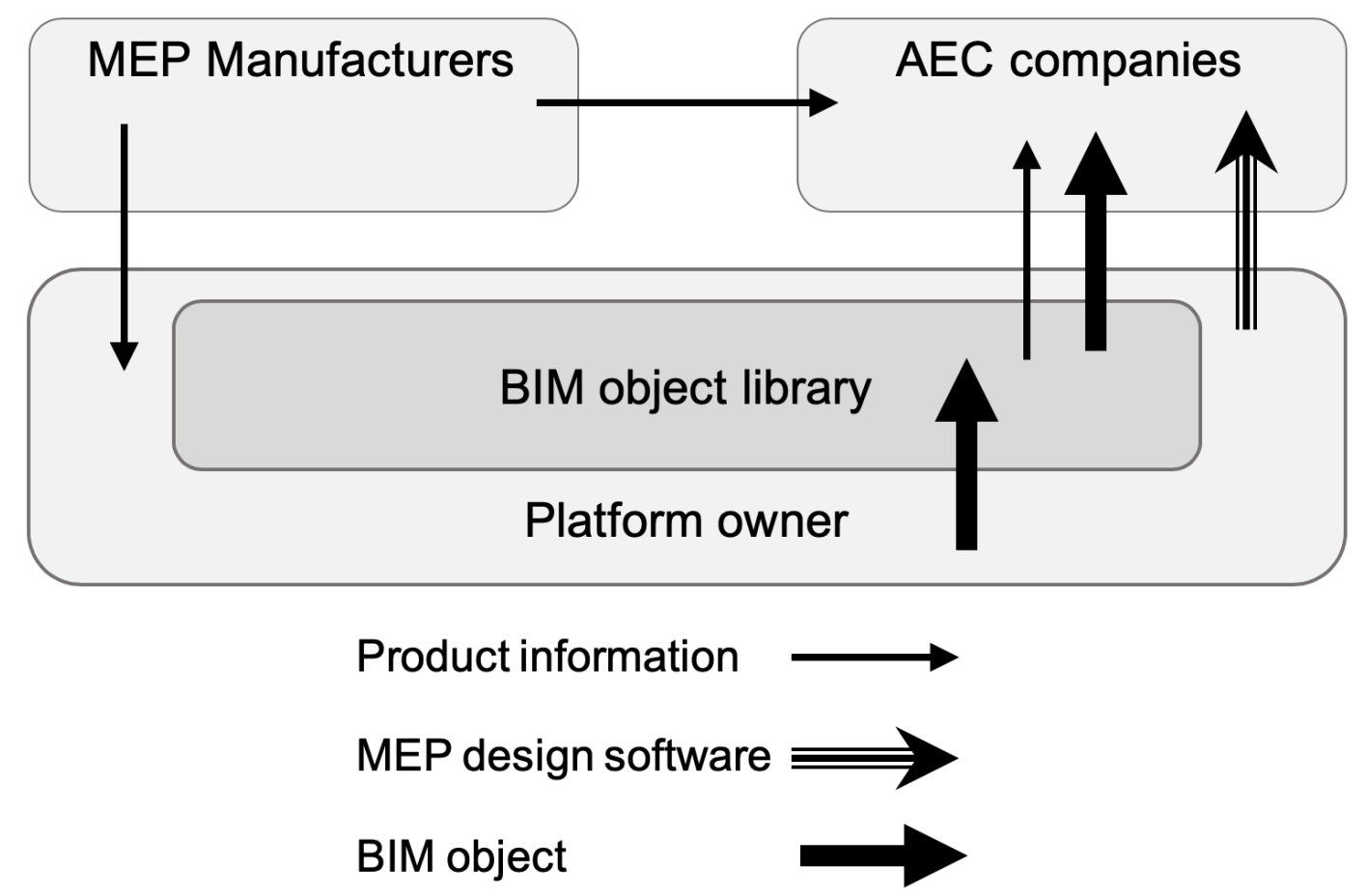

Fig. 4. Interactions on platform A

and plugins; the latter connect the manufacturers' product selection and calculation software to the MEP design software. Manufacturers must pay the platform owner for creating BIM objects and plugins and maintaining BIM objects in the library. According to the interviewees in manufacturing companies, these services are expensive. For ventilation products in Sweden, 93 brands have BIM objects on this platform, while the number of objects is very limited in comparison with the number of products available in the market. More than $50 \%$ of the available BIM objects belong to five main brands in the country.

As shown, the manufacturers send their product data sheets to the platform owner for creating the BIM objects. The users of BIM objects at AEC companies access the BIM objects and install plugins through either the design software offered by the platform owner or the library interface. According to the platform A's area manager, more than 95\% of HVAC designers in Sweden use the design software offered by the platform. The designers using Revit instead of the software have free access to a mere $20 \%$ of BIM objects. That can be increased to $70 \%$ by purchasing the premium version of the connection tool while they must purchase the software in order to gain full access. This represents a closed strategy where the platform owner uses its products and services to control the interactions on its BIM library platform.

Figure 5 shows the interactions among participants on platform B. This platform has a wider range of participants including architects, MEP designers, those involved in purchasing building products in AEC companies, and third-party software developers. The platform owner has opened the development of BIM objects to building product manufacturers and third-party developers by providing them with required application programming interface (API) and software 

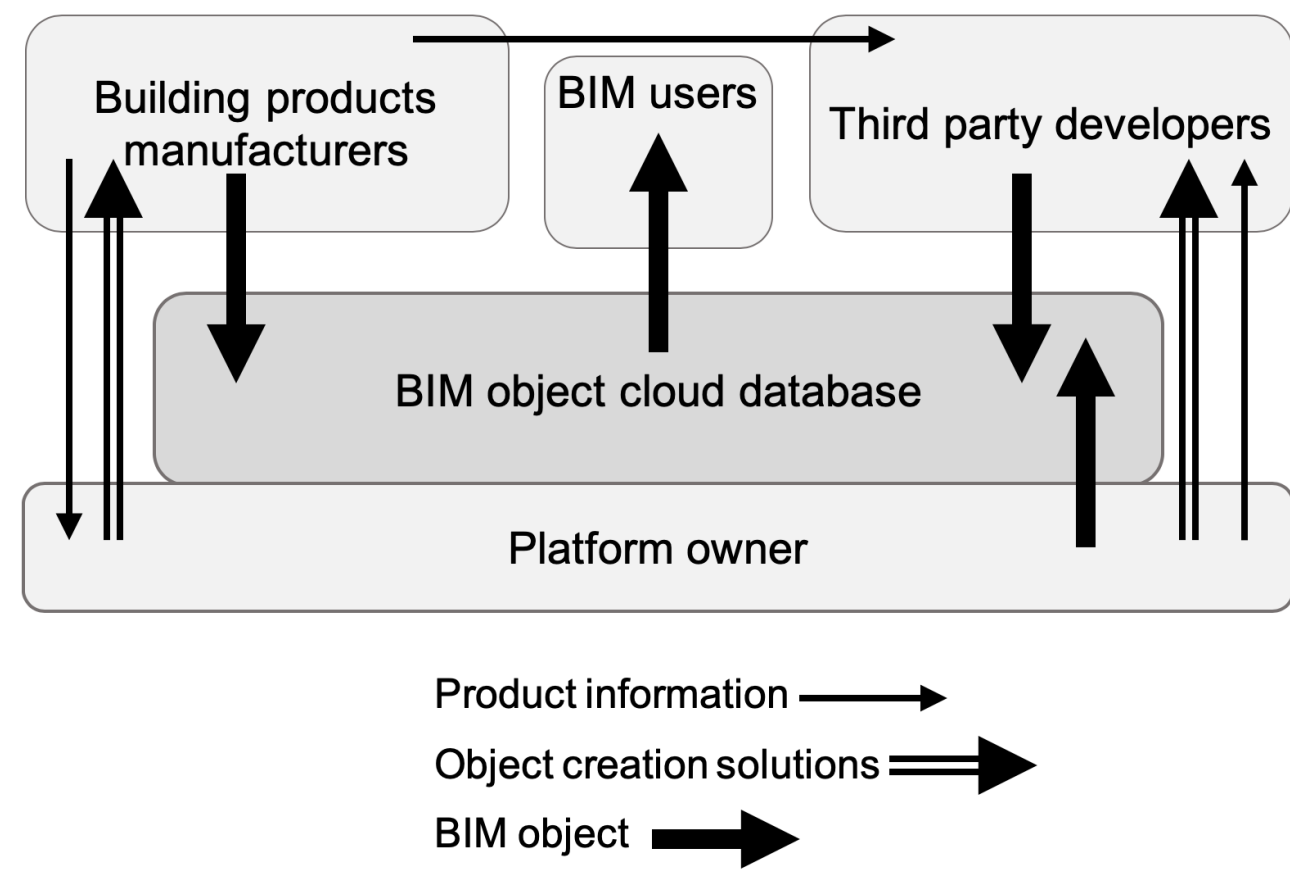

Fig. 5. Interactions on platform B

solutions. Thus, manufacturers can create and publish BIM objects on the platform's cloud database. They can also outsource the creation of the BIM objects to the platform owner or third-party developers. The software solutions supplied to manufacturers include tools for using the BIM object cloud database in business analytics and marketing applications. However, for ventilation products in Sweden, merely 26 brands have BIM objects on platform B, which is 3.4 times fewer than the brands on platform A. Another interesting finding is that the main HVAC brands in the country are not active on platform B. As a new strategy for motivating interactions on their platforms, both platform owners approach facility owners, i.e. the AEC companies' clients, to increase their awareness of BIM and its impacts on facility management. In other words, they encourage the facility owners to demand BIM-based workflows and create a demand-pull mechanism for creating high quality BIM objects.

\subsection{The usability of the BIM libraries}

None of the platforms have sufficient number of BIM objects to represent the market for ventilation products in Sweden. According to the interviewees at HVAC manufacturing companies, creating BIM objects for every product is impossible due to technical limitations of the platforms, existing methods of creating BIM objects, required resources, and associated costs. Another important finding is that the usability of BIM libraries in supporting the diffusion of innovative products has been impeded by inadequacy of information and improper architecture of the websites. On platform A, BIM objects can be searched by product type (e.g. ventilation), BIM application (Revit or AutoCAD), and country. It is also possible to search by keywords to find 
a specific product or manufacturer. A search for ventilation BIM objects in Sweden resulted in 16270 product families across 93 brands. The search results could not be filtered by the sustainability attributes of products. Clicking on an object opens a window with brief information about the product and a link to the manufacturer's websites. The user might find the information about the sustainability attributes of products through links to the manufacturers' websites or requests sent to the manufacturers. That means the user has to select an object randomly and search for the information outside the platform. Downloading plugins enables users to access manufacturers' product selection and calculation tools; however, the number of available plugins is very limited.

On platform B, BIM objects can be searched by brand, category, file type, country, and object type. Ventilation objects are classified as subcategories of HVAC which is one of the 22 categories of the BIM objects. Searching for ventilation BIM objects in Sweden resulted in 428 product families across 26 brands, which means that in the scope of the search, platform A had 38 times more BIM objects and around 3.4 times more brands than platform B. The most likely explanation is that targeting the MEP sector as a niche market has helped platform A to allocate professional resources and satisfy the specific needs of its users. Similar to platform A, searching for BIM objects on platform B by the sustainability attributes was impossible and the only way to access such information was random selection of an object and through links to the manufacturers' websites. Therefore, neither platform A nor platform B enables users to apply the sustainability attributes of products as a basis for comparison between different brands.

\subsection{The quality of BIM objects}

The quality and reliability of BIM objects on the platforms is not assured through any thirdparty certification schemes. The BIM objects on platform A are compatible with Revit and the design and calculation software offered by the platform. As noted, the latter is used by over 95\% of HVAC designers in Sweden. However, the objects are not sufficient to perform accurate calculations; users need access to manufacturers' selection and calculation tools through plugins. The information about the sustainability attributes was missing in $12 \%$ of the selected objects and it was inadequate in the other ones. Regarding the currency of information, the date of the edition is provided, but that does not necessarily mean the BIM object has up-to-date information.

On platform B, Revit and AutoCAD are among 53 available file formats. Despite that, the available BIM objects cannot be used to perform calculations required in HVAC design or to predict the sustainability performance of HVAC products. By selecting a BIM object from the search results, users access an internal page with the product information including identification data and menus for descriptions, classifications, properties, and links to the manufacturers' technical data sheets and websites. Only $10 \%$ of selected objects had statements about sustainability attributes and certifications. The information architecture of BIM objects on platform B facilitates access to categorized information. However, both missing and misplaced information were detected as problems with the content of the objects. For each object, information about the date of publication and the edition number is provided. Users can access the latest version of an 
object by clicking on the "update" button in a downloaded object. It is not yet clear whether the manufacturer has updated its product information.

As inferred from the interviews, the functionality of BIM objects in design and calculation software is critical for manufacturers in order to differentiate their products. This appears not to be a major concern for AEC companies, unless their clients (e.g. facility owners) demand it. The accuracy of product information is not controlled in any of the platforms. Therefore, if there is an error, as found in some acoustic information provided by manufacturers, it remains in the content of the BIM object. Both platforms are faced with the same problem of inadequate information about the sustainability attributes of products. Comprehensibility of the information is another neglected issue on both platforms. Although some information in manufacturers' technical data sheets is confusing (e.g. the terms, notations, and units used for representing the acoustic performance of the products), it forms the content of the BIM objects. Product information provided by manufacturers is the sole source of information about the sustainability attributes of BIM objects. Thus, the problem of heterogeneous methods used by manufacturers for presenting sustainability performance of their products (Bahrami et al., 2019) hinders comparisons between different brands.

\section{Implications}

\subsection{Implications for BIM platform owners}

This study found that users in AEC companies cannot select sustainability attributes as the search criteria for finding products on the studied platforms. Consequently, BIM libraries are unable to provide manufacturers with the opportunity of differentiating their sustainable products and creating sustainable value through the diffusion of their innovations. Adopting an effective business strategy is a major challenge for platform owners (Van Alstyne et al., 2016). Platform A is limited to the MEP sector and generates profit by selling MEP design and calculation software as well as creating BIM objects and plugins. The platform owner creates BIM objects in a closed system which is easier to control and monetize; however, increasing the friction through strict controls can reduce participation and impede value creation in a platform (Parker et al. 2017a). In contrast, platform B is open to various BIM users and generates profit by selling software solutions for creating BIM objects and BIM-based supply and marketing solutions. This strategy might enable the platform owner to absorb innovative solutions (Parker \& Van Alstyne, 2018) for creating BIM objects in the future.

The large difference between the BIM object for HVAC products on platform A and platform $\mathrm{B}$ shows the significance of allocating professional resources by platform A to satisfy user requirements for HVAC applications. Another contributory factor is that more than $95 \%$ of HVAC designers at AEC companies in Sweden use the design software offered by platform A. Therefore, HVAC manufacturers in the country prefer BIM library platform A as the database for their BIM objects. Nonetheless, even on this platform, BIM objects are not available for a large number of available products in the market. As confirmed by our interviewees in manufacturing companies, this problem is caused by current methods of creating and maintaining BIM objects on the 
libraries and the associated costs. Thus, BIM library platform owners need efficient methods for creating BIM objects to increase the interactions on their platforms.

Increasing the facility owners' awareness of BIM is a viable strategy adopted by both platforms to generate demand for BIM objects and increasing the interactions on the platforms. Moreover, platform B's BIM-based marketing and supply solutions have a great potential to stimulate demand for high-quality BIM objects. Such objects can increase the accuracy of design calculations and performance simulations and enable the users to select the innovative products with enhanced sustainability performance. To create high-quality BIM objects for HVAC products and satisfy the specific needs of HVAC professionals, platform owners must acquire proper expertise. Nonetheless, creating high-quality BIM objects in supporting the diffusion of innovations needs high quality product information to be provided by HVAC manufacturers.

\subsection{Implications for manufacturers}

To trigger the diffusion of their sustainable innovations through BIM library platforms, manufacturers must effectively communicate the information about their products by high-quality BIM objects. This study identified that manufacturers have not provided high-quality product information for the content of BIM objects. As a result, BIM library owners are unable to provide BIM library interfaces which include sustainability attributes of the products in their search criteria. Consequently, the users at AEC companies cannot search for products with superior sustainability attributes on BIM library platforms. For example, they cannot search for BIM objects for energy efficient fans and find a fan which is more energy efficient than the other brands. Supporting the diffusion of innovations with enhanced sustainability performance through BIM libraries requires affecting the user's perception by communicating high-quality information embedded in BIM objects. Moreover, high-quality BIM objects enable designers to perform more realistic designs and simulations that can affect the user's perception of a product by virtual trialability and observability. Creating high-quality BIM objects needs product information that is accurate, adequate, comprehensible, applicable, and reliable. This study suggests that manufacturers must implement effective product information management systems and consider integrating the creation of BIM objects into the PLM tools. This could facilitate the creation of BIM objects for all products and provide platform owners with the information they need to improve the architecture and enhance the usability of their BIM library interfaces.

\subsection{Implications for research}

This study has developed an interdisciplinary approach to explore the functionality of two BIM object platforms as the enablers for the diffusion of innovations with enhanced sustainability performance. The broad conceptual framework enables a holistic approach in investigating various factors and stakeholders involved, while the focus on the specific case of ventilation products in the Swedish market deepens the understanding about related problems. Figure 6 illustrates the proposed model for presenting the theoretical effects of a BIM library platform on communicating the information about an innovation, influencing the user's perception of its characteristics, and consequently its diffusion. As shown, a BIM library platform influences the diffusion of 


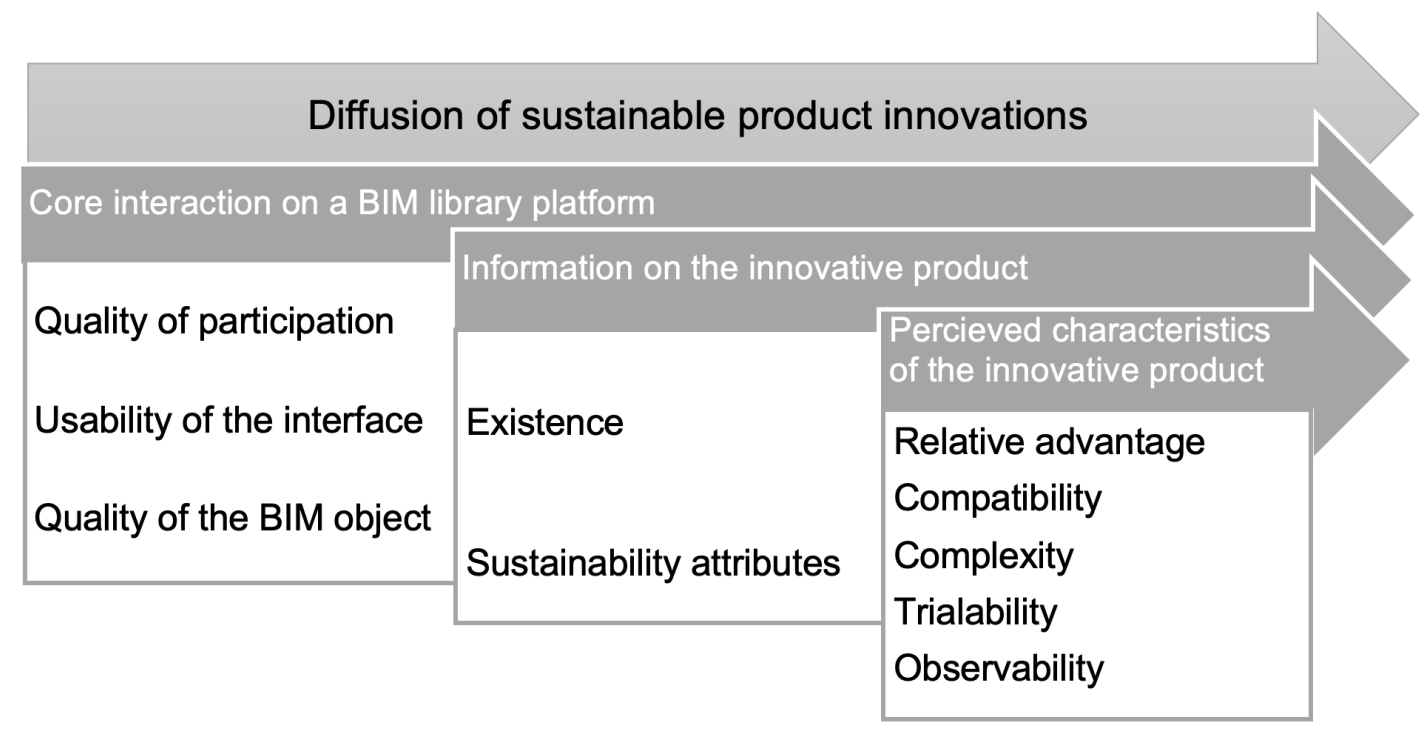

Fig. 6. The role of the BIM library platforms in the diffusion of sustainable innovative products

sustainable innovative products through its core interaction of which three key elements are the quality of participation, the usability of its interface, and the quality of its BIM objects. The sustainability attributes can be defined based on each case study e.g. energy efficiency, indoor environmental quality performance, and carbon footprint of the products. The characteristics are defined in the methodology section (table 1).

\section{Conclusions}

The present study was designed to investigate the creation and exchange of BIM objects on two BIM library platforms in supporting the diffusion of sustainable HVAC innovations. BIM platform library platforms have a pivotal role to play in the exchange of information about innovative HVAC products with enhanced sustainability attributes, and consequently the diffusion of such innovations. Nevertheless, the findings of this study indicate that this role has not been served by the platforms studied. On both platforms, access to information about the existence of products is very limited. In addition, poor quality of BIM objects prevents virtual trialability of products and observability of their sustainability performance. Thus, manufacturers cannot show the sustainability attributes of their products and affect the user perception of their sustainable innovations. This in turn, hinders the diffusion of their sustainable innovations through BIM platforms. The causal factors are low-quality product information provided by manufacturers, ineffective mechanisms for creating BIM objects, ineffective strategies for attracting participants to the platforms, and usability problems of BIM library interfaces.

These findings suggest that HVAC manufacturers need effective mechanisms for creating BIM objects. Integrating BIM object creation into the PLM systems is recommended as a solution. This could facilitate providing high-quality product information that enables platform owners 
to improve the information architecture and usability of their BIM libraries in supporting the diffusion of sustainable innovations. Platform owners must consider the technical requirements for the HVAC applications in order to attract HVAC professionals at AEC companies to the BIM libraries. The growing application of BIM makes the BIM object quality as significant as the product quality. Therefore, quality assurance and certification schemes such as the BSI Kitemark for BIM objects are recommended to be developed according to the national regulations in order to ensure the quality of BIM objects by third party certification bodies. Addressing these issues requires active collaboration among BIM platform owners, HVAC product manufacturers, AEC companies, and facility owners. The generalization of the findings is limited due to the study being constrained to the use of just two BIM library platforms in Sweden. Nevertheless, we believe that our study could be a framework for future studies on the use of BIM libraries in supporting sustainable innovations. Another significant area of further research is the feasibility of integrating BIM object creation into the PLM systems. Moreover, this study was not specifically designed to evaluate the monetization strategies adopted by the platform owners. Therefore, further research is needed to investigate the effects of platform monetization strategies on the exchange of information through the platforms and the diffusion of sustainable innovations.

\section{References}

Anderson, J. C., Narus, J. A., \& Narayandas, D. (2009). Business market management: understanding, creating, and delivering value (3rd ed.). Upper Saddle River, NJ: Pearson Education Inc.

Anumba, C. J., Issa, R. R. A., Pan, J., \& Mutis, I. (2008). Ontology-based information and knowledge management in construction. Construction Innovation, 8(3), 218-239. https://doi. org $/ 10.1108 / 14714170810888976$

Bahrami, S., Negreira, J., Olander, S., \& Landin, A. (2019). Communicating the Acoustic Performance of Innovative HVAC Solutions. In D. Johansson, H. Bagge, \& A. Wahlström (Eds.), Cold Climate HVAC 2018, Springer Proceedings in Energy. Springer, Cham. https://doi.org/https://doi.org/10.1007/978-3-030-00662-4_91

Bass, F. M. (2004). Comments on "A New Product Growth for Model Consumer Durables": The Bass Model. Management Science, 50(12), 1833-1840. https://doi.org/10.1287/mnsc.1040. 0300

Beach, D., \& Pedersen, R. B. (2013). Process-tracing methods: foundations and guidelines. University of Michigan Press.

Bhaskar, R. (2014). Foreword. In Studying Organizations Using Critical Realism: A Practical Guide (pp. v-xvi). Oxford Scholarship Online. https://doi.org/10.1093/acprof:oso/9780199665525. 001.0001

Bhaskar, R., Frank, C., Høyer, K. G., Næss, P., \& Parker, J. (Eds.). (2010). Interdisciplinarity and Climate Change: Transforming knowledge and practice for our global future. London: Routledge. 
Bhimani, H., Mention, A.-L., \& Barlatier, P.-J. (2019). Social media and innovation: A systematic literature review and future research directions. Technological Forecasting and Social Change, 144, 251-269. https://doi.org/https://doi.org/10.1016/j.techfore.2018.10.007

Bianchi, M., Di Benedetto, A., Franzò, S., \& Frattini, F. (2017). Selecting early adopters to foster the diffusion of innovations in industrial markets. European Journal of Innovation Management, 20(4), 620-644. https://doi.org/10.1108/ejim-07-2016-0068

Bimobject. (2019). bimobject content platform. Accessed 25th July 2019. https://www. bimobject.com/en/product

Bosch-Sijtsema, P., Isaksson, A., Lennartsson, M., \& Linderoth, H. C. J. (2017). Barriers and facilitators for BIM use among Swedish medium-sized contractors - "We wait until someone tells us to use it." Visualization in Engineering, 5(1). https://doi.org/10.1186/s40327-017-0040-7

Bryman, A., \& Bell, E. (2015). Business research methods (4th ed.). Oxford: Oxford University Press.

BSI. (2018). Little book of BIM For Manufacturers. The British Standards Institution. Accessed 19th December 2018. http://page.bsigroup.com/lbb-for-manufacturers-uk?utm_source= pardot\&utm_medium $=$ online\&utm_content $=$ bsi-website-bim-objects\&utm_campaign $=$ BP7

Chen, K., Lu, W., Wang, H., Niu, Y., \& Huang, G. G. (2017). Naming Objects in BIM: A Convention and a Semiautomatic Approach. Journal of Construction Engineering and Management, 143(7), 06017001. https://doi.org/10.1061/(asce)co.1943-7862.0001314

Creswell, J. W., \& Poth, C. N. (2018). Qualitative inquiry 83 research design: choosing among five approaches (4th ed.). Los Angeles: Sage Publications, Inc.

Danermark, B., Ekström, M., Jakobsen, L., \& Karlsson, J. C. (2002). Explaining Society: Critical realism in the social sciences. London; New York: Routledge.

Davenport, T. H., \& Prusak, L. (2000). Working knowledge: How organizations manage what they know (2nd ed.). Harvard Business Review Press.

Feather, J. (2013). Information rich and information poor. In The information society: A study of continuity and change (6th ed., pp. 75-134). London, United Kingdom: Facet Publishing.

Fehrer, J. A., Woratschek, H., \& Brodie, R. J. (2018). A systemic logic for platform business models. Journal of Service Management, 29(4), 546-568. https://doi.org/10.1108/JOSM-022017-0036

Ferreira, F., Faria, J., Azevedo, A., \& Marques, A. L. (2017). Product lifecycle management in knowledge intensive collaborative environments: An application to automotive industry. International Journal of Information Management, 37(1), 1474-1487. https://doi.org/10.1016/j. ijinfomgt.2016.05.006

Frattini, F., Bianchi, M., De Massis, A., \& Sikimic, U. (2014). The role of early adopters in the diffusion of new products: Differences between platform and nonplatform innovations. Journal of Product Innovation Management, 31(3), 466-488. https://doi.org/10.1111/jpim.12108 
Gao, G., Liu, Y. S., Lin, P., Wang, M., Gu, M., \& Yong, J. H. (2017). BIMTag: Conceptbased automatic semantic annotation of online BIM product resources. Advanced Engineering Informatics, 31, 48-61. https://doi.org/10.1016/j.aei.2015.10.003

Gholizadeh, P., Esmaeili, B., \& Goodrum, P. (2018). Diffusion of Building Information Modeling Functions in the Construction Industry. Journal of Management in Engineering, 34(2), 04017060. https://doi.org/10.1061/(ASCE)ME.1943-5479.0000589

Gledson, B. (2017). Innovation Diffusion within the UK Construction Sector: a study of the adoption of $4 D$ BIM. Northumbria University.

Goertz, G., \& Mahoney, J. (2012). Causal Mechanisms and Process Tracing. In A Tale of Two Cultures: Qualitative and Quantitative Research in the Social Sciences. Princeton University Press. https://doi.org/10.23943/princeton/9780691149707.001.0001

Grimpe, C., Sofka, W., Bhargava, M., \& Chatterjee, R. (2017). R\&D, Marketing Innovation, and New Product Performance: A Mixed Methods Study. Journal of Product Innovation Management, 34(3), 360-383. https://doi.org/10.1111/jpim.12366

Hall, B. H. (2006). Innovation and Diffusion. In The Oxford Handbook of Innovation. Oxford University Press. https://doi.org/10.1093/oxfordhb/9780199286805.003.0017

Holliman, G., \& Rowley, J. (2014). Business to business digital content marketing: Marketers' perceptions of best practice. Journal of Research in Interactive Marketing, 8(4), 269-293. https: //doi.org/10.1108/JRIM-02-2014-0013

Holmström, J., Singh, V., \& Främling, K. (2014). BIM as Infrastructure in a Finnish HVAC Actor Network: Enabling Adoption, Reuse, and Recombination over a Building Life Cycle and between Projects. Journal of Management in Engineering, 31(1), A4014006. https://doi.org/10. 1061/(asce)me.1943-5479.0000305

Hooper, M. (2015). Bim standardisation efforts - The case of Sweden. Journal of Information Technology in Construction, 20, 332-346.

Huberman, A., \& Miles, M. (Eds.). (2002). The Qualitative Researcher's Companion. Thousand Oaks, California: Sage Publications, Inc. https://doi.org/10.4135/9781412986274

ISO. (2018). ISO 14067:2018(en), Greenhouse gases - Carbon footprint of products - Requirements and guidelines for quantification. Accessed 19th July 2019. https://www.iso.org/obp/ui/ \#iso:std:iso:14067:ed-1:v1:en

ISO. (2019). ISO/IEC 25062:2006 Software engineering -- Software product Quality Requirements and Evaluation (SQuaRE) -- Common Industry Format (CIF) for usability test reports. Accessed 17th February 2019. https://www.iso.org/standard/43046.html

Kessler, I., \& Bach, S. (2014). Comparing Cases. In P. K. Edwards, J. O’Mahoney, \& S. Vincent (Eds.), Studying Organizations Using Critical Realism (pp. 168-184). Oxford University Press. https://doi.org/10.1093/acprof:oso/9780199665525.003.0009

Kim, J. (2016). The platform business model and business ecosystem: quality management and revenue structures. European Planning Studies, 24(12), 2113-2132. https://doi.org/10.1080/ 09654313.2016 .1251882 
Kohler, T., \& Chesbrough, H. (2019). From collaborative community to competitive market: the quest to build a crowdsourcing platform for social innovation. R\&5D Management, 49(3), 356-368. https://doi.org/10.1111/radm.12372

Leising, E., Quist, J., \& Bocken, N. (2018). Circular Economy in the building sector: Three cases and a collaboration tool. Journal of Cleaner Production, 176, 976-989. https://doi.org/ 10.1016/j.jclepro.2017.12.010

Lindic, J., \& Silva, C. M. Da. (2011). Value proposition as a catalyst for a customer focused innovation. Management Decision, 49(10), 1694-1708. https://doi.org/10.1108/00251741111183834

MagiCAD. (2019). MagiCloud BIM Library. Accessed 20th October 2019. https://www. magicloud.com/products/

Makri, S., Blandford, A., \& Cox, A. L. (2008). Using Information Behaviors to Evaluate the Functionality and Usability of Electronic Resources: From Ellis's Model to Evaluation. Journal of the American Society for Information Science and Technology, 59(14), 2244-2267. https: //doi.org/10.1002/asi.20927

Mathison, S. (Ed.). (2005). Cross-Case Analysis. In Encyclopedia of Evaluation. Thousand Oaks, California: Sage Publications, Inc. https://doi.org/10.4135/9781412950558.n129

Mauthner, N. S., \& Doucet, A. (2003). Reflexive Accounts and Accounts of Reflexivity in Qualitative Data Analysis. Sociology, 37(3), 413-431. https://doi.org/10.1177/00380385030373002

McGlinn, K., Yuce, B., Wicaksono, H., Howell, S., \& Rezgui, Y. (2017). Usability evaluation of a web-based tool for supporting holistic building energy management. Automation in Construction, 84(August), 154-165. https://doi.org/10.1016/j.autcon.2017.08.033

Myrelid, P., \& Jonsson, P. (2019). Determinants of information quality in dyadic supply chain relationships. International Journal of Logistics Management, 30(1), 356-380. https://doi.org/ 10.1108/IJLM-12-2017-0343

National Building Specification. (2019). NBS National BIM Library. Accessed 20th October 2019. https://www.nationalbimlibrary.com/en/

Nidumolu, R., Prahalad, C. K., \& Rangaswami, M. R. (2009). Why sustainability is now the key driver of innovation. Harvard Business Review, 87(9), 57-64. https://doi.org/10.1109/EMR. 2015.7123233

Olson, E. L. (2013). Perspective: The green innovation value chain: A tool for evaluating the diffusion prospects of green products. Journal of Product Innovation Management, 30(4), 782-793. https://doi.org/10.1111/jpim.12022

Osterwalder, A., Pigneur, Y., Bernarda, G., \& Smith, A. (2014). Value proposition design: how to create products and services customers want. Hoboken, New Jersey: John Wiley \& Sons.

Palos, S., Kiviniemi, A., \& Kuusisto, J. (2014). Future perspectives on product data management in building information modeling. Construction Innovation, 14(1), 52-68.

Parker, G., \& Van Alstyne, M. (2018). Innovation, Openness, and Platform Control. Management Science, 64(7), 3015-3032. https://doi.org/10.1287/mnsc.2017.2757 
Parker, G., Van Alstyne, M., \& Choudary, S. P. (2017a). Architecture. In Platform Revolution. New York: W. W. Norton \& Company Ltd.

Parker, G., Van Alstyne, M., \& Choudary, S. P. (2017b). Openness: Defining What Platform Users and Partners Can and Cnnot Do. In Platform revolution (pp. 129-156). New York: W. W. Norton \& Company Ltd.

Parker, G., Van Alstyne, M. W., \& Choudary, S. P. (2017c). Today. In Platform Revolution (pp. 5-15). New York: W.W. Norton \& Company.

Parker, G., Van Alstyne, M. W., \& Jiang, X. (2017). Platform Ecosystems: How Developers Invert the Firm. MIS Quarterly, 41(1), 255-266. https://doi.org/10.2139/ssrn.2861574

Pasini, D., Caffi, V., Daniotti, B., Lupica Spagnolo, S., \& Pavan, A. (2017). The INNOVance BIM library approach. Innovative Infrastructure Solutions, 2(1), 1-9. https://doi.org/10.1007/ s41062-017-0062-y

Patala, S., Jalkala, A., Keränen, J., Väisänen, S., Tuominen, V., \& Soukka, R. (2016). Sustainable value propositions: Framework and implications for technology suppliers. Industrial Marketing Management, 59, 144-156. https://doi.org/10.1016/j.indmarman.2016.03.001

Payne, A., Frow, P., \& Eggert, A. (2017). The customer value proposition: evolution, development, and application in marketing. Journal of the Academy of Marketing Science, 45(4), 467-489. https://doi.org/10.1007/s11747-017-0523-z

Pazeraite, A., \& Repoviene, R. (2016). Content marketing elements and their influence on search advertisement effectiveness: theoretical background and practical insights. Management of Organizations: Systematic Research, 75, 97-109. https://doi.org/doi:10.7220/MOSR.2335. 8750.2016.75.7

Peter, S., DeLone, W. H., \& McLean, E. R. (2013). Information systems success: The quest for the dependent variable. Journal of Management Information Systems, 29(4), 7-61. https: //doi.org/10.2753/MIS0742-1222290401

Rice, R. E. (2017). Intermediality and the Diffusion of Innovations. Human Communication Research, 43(4), 531-544. https://doi.org/10.1111/hcre.12119

Rogers, E. M. (2003). Diffusion of Innovations (5th ed.). New York: Free Press.

Rowley, J. (2008). Understanding digital content marketing. Journal of Marketing Management, 24(5-6), 517-540. https://doi.org/10.1362/026725708X325977

Saunders, M., Lewis, P., \& Thornhill, A. (2009). Research methods for business students. RoFo: Fortschritte auf dem Gebiete der Rontgenstrahlen und der Nuklearmedizin (5th ed., Vol. 176). Harlow, England: Pearson Education Limited.

Schuh, G., Rozenfeld, H., Assmus, D., \& Zancul, E. (2008). Process oriented framework to support PLM implementation. Computers in Industry, 59(2-3), 210-218. https://doi.org/10. 1016/j.compind.2007.06.015

Singh, K. D. (2015). Creating Your Own Qualitative Research Approach: Selecting, Integrating 
and Operationalizing Philosophy, Methodology and Methods. Vision, 19(2), 132-146. https: //doi.org/10.1177/0972262915575657

SmartBIM. (2018). SmartBIM. Accessed 23rd July 2019. https://www.smartbimtechnologies. $\mathrm{com} /$

Song, M., \& Parry, M. E. (2009). Information, promotion, and the adoption of innovative consumer durables. Journal of Product Innovation Management, 26(4), 441-454. https://doi. org/10.1111/j.1540-5885.2009.00670.x

Speicher, M., Both, A., \& Gaedke, M. (2015). INUIT: The Interface Usability Instrument. In Aaron Marcus (Ed.), Design, User Experience, and Usability: Design Discourse (Vol. 9186, pp. 256-268). Springer.

Stark, J. (2015). Product Lifecycle Management (Volume 1) 21st Century Paradigm for Product Realisation (Third, Vol. 1, p. 14). Geneva: Springer International Publishing AG Switzerland. https://doi.org/10.1007/978-3-319-17440-2

Sulkowski, A. J., Edwards, M., \& Freeman, R. E. (2018). Shake Your Stakeholder: Firms Leading Engagement to Cocreate Sustainable Value. Organization and Environment, 31(3), 223-241. https://doi.org/10.1177/1086026617722129

Sweden Green Building Council. (2019). Miljö Byggnad 3.0 Nyproduktion [Environment Building 3.0 New Construction]. Accessed 10th September 2019. https://www.sgbc.se/certifiering/ miljobyggnad/certifieringsstod-for-miljobyggnad/manualer-och-verktyg-for-certifiering-i-miljobyggnad/

Talmar, M., Walrave, B., Podoynitsyna, K. S., Holmström, J., \& Romme, A. G. L. (2018). Mapping, analyzing and designing innovation ecosystems: The Ecosystem Pie Model. Long Range Planning, (September), 101850. https://doi.org/10.1016/j.lrp.2018.09.002

Tarkkanen, K., Harkke, V., \& Reijonen, P. (2015). Are We Testing Utility? Analysis of Usability Problem Types. In A. Marcus (Ed.), Design, User Experience and Usability. Design Discourse. 4th International Conference, DUXU 2015 (pp. 269-280). Cham Switzerland. https://doi.org/ 10.1007/978-3-319-20886-2_26

Van Alstyne, M., \& Parker, G. (2017). Platform Business: From Resources to Relationships. GfK Marketing Intelligence Review, 9(1), 24-29. https://doi.org/10.1515/gfkmir-2017-0004

Van Alstyne, M., Parker, G. G., \& Choudary, S. P. (2016). Pipelines, Platforms, and the New Rules of Strategy. Harvard Business Review, 94(4), 54-62. https://doi.org/https://hbr.org/2016/04/pipelinesplatforms-and-the-new-rules-of-strategy

World Intellectual Property Organization. (2015). (WO2015122831) VENTILATION DEVICE WITH REDUCED SOUND GENERATION. Accessed 23rd October 2019. https://patentscope. wipo.int/search/en/detail.jsf?docId=WO2015122831\&_cid=P12-JYEM46-11870-3

World Intellectual Property Organization. (2018). (WO2018174776) SELF-ADJUSTED SUPPLY AIR TERMINAL. Accessed 23rd October 2019. https://patentscope.wipo.int/search/en/ detail.jsf?docId=WO2018174776\&_cid=P12-JYEMKT-14808-1

Yin, R. K. (2016). Qualitative Research from Start to Finish (2nd ed.). New York: The Guilford Press. 
Yin, R. K. (2018). Case study research and applications: Design and methods (6th ed.). Los Angeles: SAGE.

Young, L., \& Munksgaard, K. B. (2018). Analysis of Qualitative Data: Using Automated Semantic Analysis to Understand Networks of Concepts. In P. V. Freytag \& L. Young (Eds.), Collaborative Research Design: Working with Business for Meaningful Findings (pp. 251-284). Singapore: Springer Singapore. https://doi.org/10.1007/978-981-10-5008-4_11 


\section{Biographies}

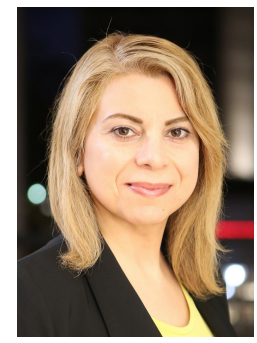

Soheila Bahrami. Soheila Bahrami received her Licentiate degree in construction and architectural engineering from Lund University, Sweden in 2019. She holds an MEng degree in mechanical engineering-HVAC systems from the University of Western Ontario in Canada, an MSc degree in environmental management from Lund University in Sweden, and a BSc degree in technical inspection engineering from the Petroleum University of Technology in Iran. She has work experience in process engineering, industrial marketing, and technical training in petrochemical and natural gas industries. Since 2008, she has been involved in research projects on innovative building ventilation systems, energy efficiency, and thermal comfort at Lund University. In 2015, she conducted research and worked as a consultant on energy management solutions for building HVAC systems in Canada. She is currently pursuing a $\mathrm{PhD}$ degree in construction management at Lund University. Her research interests include innovative ventilation systems for sustainability, exchanging product information in BIM platforms and HVAC engineering education for sustainability.

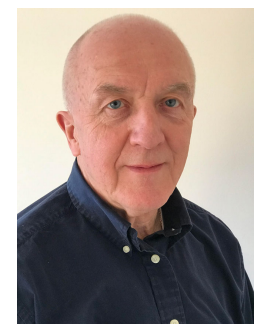

Brian Atkin. Brian Atkin gained his doctorate from the University of Reading in the UK. He holds a master's degree by research into the costs of major engineering infrastructure. Presently, he is Professor in the Division of Construction Management at Lund University, Lund, Sweden and Adjunct Professor in the School of Civil Engineering and Built Environment, Queensland University of Technology, Brisbane, Australia. Brian has also held professorial and visiting fellow positions in the UK, Hong Kong, Finland and Iceland. As a member of the British Standards Institution (BSI) Facilities Management Strategy Group and Technical Committee, he has been closely involved in the drafting of all national standards in facilities management. In addition, he represents BSI on the International Standards Organization Technical Committee for Facility Management where he has also been involved in drafting. Brian is co-author of the standard textbook on Total Facility Management and the author of numerous research papers and reports. His work as an examiner covers all levels, including higher doctorates.

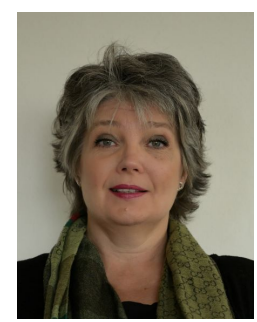

Anne Landin. Anne Landin gained her Doctorate from Lund University, where she is Professor and Head of the Department of Construction Management. In 2007, she received the award of Excellent Teaching Practitioner of the Faculty of Engineering. Landin has been involved in several academic positions and commissions. Anne has a great interest in many issues related to Lund University and its students and as a consequence, she has been engaged in several contexts such as having responsibility for faculty-shared (Science \& Engineering) postgraduate courses in project management, Chairman of the Board for the Collegium Michael Hansen, a residential centre for 350 students. Anne recognises the importance of having a healthy dialogue with industry and society and has undertaken various assignments. Anne is a certified teacher for quality issues in the construction industry and has secured various consultancy commissions covering quality, environmental and management issues. During her years in academia, Anne has published many articles and has been a constant supervisor of doctoral students. Anne has also been responsible for a number of research projects both nationally and in cooperation with other countries.

\section{ISSN 2183-0606}

http://www.open-jim.org

http://creativecommons.org/licenses/by/3.0 